\title{
Sociology on the move: The demand for the humanistic digital turn*
}

\author{
S.A. Kravchenko \\ Moscow State University of International Relations \\ of the Ministry of Foreign Affairs of Russia (MGIMO University) \\ Vernadskogo Prosp., 76, Moscow, 119454, Russia
}

Federal Center of Theoretical and Applied Sociology of the Russian Academy of Sciences

Krzhizhanovskogo St., 24/35, bldg. 5, Moscow, 117218, Russia

(e-mail: sociol7@yndex.ru)

\begin{abstract}
Digitalization of society has ambivalent consequences: there are new benefits ('smart' technologies, artificial intellect, multiple knowledge), but at the same time digital risks and metamorphoses that traumatize the behavior and thinking of people, alienate them from social ties and life-worlds. These processes have become a challenge for sociology and other social sciences that strive to develop new approaches, among which the digital and humanistic turns are the most relevant. The author aims at (a) analyzing the impact of digitalization on the production of metamorphoses and side effects on society and man, which are related to new complex risks and manifest challenges to sociology; (b) developing the contours of the conception of 'the digital turn in sociology' and identifying its essence in comparison with other, previous turns in sociology - linguistic, risk, cultural, etc.; (c) proposing the means that allow to overcome or minimize the side effects of the existing type of digitalization - the author argues for the demand to move sociology in the direction of the integral use of the instruments of the digital and humanistic turns. The article considers new challenges to mankind and scientific knowledge as determined not so much by the very process of digitalization, but by its existing type based on principles of formal rationality, pragmatism, and mercantilism neglecting, in fact, life-worlds of people. This type of digitalization is not 'universal' and can be changed by an alternative humanistic trend of digitalization. In order to begin establishing the humanistic trend of digitalization scientists should integrate the theoretical instruments of the proposed digital turn with other interdisciplinary turns and especially with the humanistic turn.
\end{abstract}

Key words: complex society; digitalization; side effects; digital risks; digital metamorphosis; centrifugal tendencies; digital turn; humanistic turn

One of the main features of the emerging complex society is digitalization which has the objective grounds: the current fourth industrial revolution radically transforms society and man. The consequences of digitalization are ambivalent: on the one hand, 'the digital' empowers people with new 'smart' technologies based on artificial intellect, provides with an immediate access to multiple knowledge; on the other hand, digitalization leads to uncertainties beyond the 'world risk society' which have already produced the following vulnerabilities: (1) 'delocalization' (its risks are not limited to the geographical space); (2) 'incalculability' (its consequences are basically incalculable);

* C S.A. Kravchenko, 2019.

The article was submitted on 03.04.2019. The article was accepted on 23.05.2019. 
(3) 'incompensability' (no money can make up for irreversible climate change or interventions in human genetics) [2. P. 52]. These risks have not disappeared and continue to produce traumatic and uncertain effects. However, even greater uncertainties and vulnerabilities have appeared due to the emergence of the 'digital risk' and the 'digital metamorphosis of society, intersubjectivity and subjectivity'. Moreover, the new digital realities release people from social, cultural and humane bonds, determine centrifugal tendencies and produce "digital humans, whose metamorphosed existence questions traditional categories, such as status, social identity, collectivity and individualization" [3. P. 141, 146]. They also do harm by producing e-waste and potential threats of 'liquid catastrophes' [17].

However, the new challenges to the mankind are not so much in the very process of digitalization but in its existing type based on such principles of management as formal rationality, pragmatism, and mercantilism neglecting life-worlds of people. This type of digitalization was chosen under the influence of wealth values and norms of the first, second, and third industrial revolutions considered as 'universal', which should be changed today. Thus, another trend of digitalization is possible - with the humanistic nature. In order to move to the humanistic digitalization, the scientists need to integrate the theoretical-methodological instruments of the digital turn in sociology with other, previous interdisciplinary turns, especially with the humanistic one.

The article is based on the complex interdisciplinary theoretical approaches such as: (a) the theory of the 'arrow of time' proposed by the Nobel prize-winner I. Prigogine, according to which everything develops increasingly quicker and in a more complex way [22] — his ideas are applied to analyze the dynamics of change from linear to nonlinear knowledge, and manifest and latent effects of technological innovations including their influence on the production of more complex risks and vulnerabilities [13. P. 312]; (b) U. Beck's theories of 'tragic individualization', 'world risk society', and 'the metamorphosis of the world' [2; 3]; (c) Ch. Perrow's theory of 'normal accidents' [20; 21]; and (d) J. Urry's paradigm of 'new catasrophism' [23]. Special emphasis is made on the first theoretical attempts to establish 'the human spirit' in the digital turn and to minimize the side effects of digitalization [19;24].

The proposed contours of the concept of the 'digital turn in sociology' are based on the synthesis of the digital and humanistic turns. In order to overcome the side effects and collateral damage of digitalization, sociologists should use the achievements of both social sciences and humanities. Such integralism, on the one hand, allows to predict complex risks and vulnerabilities, new turbulences, traumas, and metamorphoses of society; on the other hand, to 'insert' the human spirit and cultural foundations into digitalization and other technological innovations, which would allow to begin searches for new forms of humanism adequate to the contemporary complex realities. The digital turn with the humanistic essence is an ethical imperative aimed at revealing the dynamic and complex nature of the contemporary society.

To achieve this goal, we have to consider (1) the impact of digitalization on the production of metamorphoses in society and man; (2) the conception of digital turn in socio- 
logy. First, in its most general form, metamorphosis is a radical transformation of something (someone) into a different reality or quite another mode of being. In everyday life, one can observe the metamorphoses of a seed into a plant, a caterpillar into a butterfly, a tadpole into a frog. According to E. Goffman, in social life metamorphoses are quite possible: the 'normal', after being stigmatized, has the potential to become 'normal' again [10]; with appropriate efforts an individual can not only be rehabilitated but even become a celebrity [11. P. 463], and metamorphoses have become much more complex since Goffman's times.

Digitalization influences greatly the birth of the new generation of complex metamorphoses, which presuppose non-linear, irreversible changes in social life. Their essence is mainly manifested in side effects of human innovations [15. P. 3-14]. Thus, A. Elliott and J. Urry argue that digital technologies require the metamorphosis of theorizing mobilities as they produce quite another mode of social mobility in the form of miniaturized mobilities. Their side effects enter our life and other new social patters in four basic ways: 1) "mobile connectivity, which, in constituting the person as the portal, unties the self from specific locations or places and reconfigures identity as dispersed, adrift, "on the move"'; 2) "continuous coordination of communications, social networks and the mobile self"; 3) "strategic travel planning and communications scheduling become of key importance"; 4) "technological unconscious comes to the fore ... it is necessary to speak of a technological unconscious at work in the negotiation of social relations involving high degrees of absence, distance and disconnection" [9. P. 30-33]. These realities have become a part of nowadays digital life. They do not only make our life on the constant move but also radically change social, cultural, and emotional modes of being in it.

Digitalization has changed greatly the essence of communication of the industrial modern. One can see the rise of a new type of societal communication, which M. Castells conceptualized as 'mass self-communication' based on self-generated content, self-directed emission, and self-selected reception. So, there is a 'new communication realm' whose "backbone is made of computer networks, whose language is digital, and whose senders are globally distributed and globally interactive". In fact, a new metamorphosed culture develops - "the culture of real virtuality, in which the digitalized networks of multimodal communication have become so inclusive of all cultural expressions and personal experiences that they have made virtuality a fundamental dimension of our reality" [8. P. xxx, xxxi]. The culture of real virtuality provides new communicative opportunities (linking global and local at 'timeless time', reaching a mass audience), but its side effects are the erosion of life-worlds - our perception of social problems is limited to the social circle of our communication; passive forms of existence prevail, which are not focused on the development of passionarity and not aimed at socially significant transformations.

The side effects of digitalization are also manifested in the centrifugal tendencies. Not so long ago social mobilities were relatively long-term and largely structured. Nowadays there are unstructured centrifugal mobilities in the form of flows of people, 
knowledge, information and money, which are practically not controlled by states and do not depend on social-cultural practices. Today people are predisposed to these mobilities based on digital content (study, work or even love at a distance), which leads to delocalization of human ties beyond national societies, weakens and significantly changes the nature of traditional social institutions designed to act as mediators in the interests of various social groups. According to U. Beck, the 'digital risk' and the 'digital metamorphosis of society' cause the 'failure in the functioning of institutions' [3. P. 141, 146], threaten pluralism of social meanings and determine diffusion of identities. People are increasingly facing risks from other countries but do not have rooted cultural content to identify such risks. The situation is aggravated by the fact that public institutions do not efficiently confront these challenges. The dispersion of values becomes a norm we consider it as 'normal anomie' [14. P. 3-10]. As a result, people tend to get rid of institutional relations and attachments to the local cultural context, and begin to depend more on themselves, on the consequences of their own risks. Therefore, there is a decrease in controllability and at the same time an increase in risks in the process of making socially significant decisions. There are also obvious tendencies of individualized forms of existence, passive in their essence, which contribute to the development of loneliness.

Labour activity is changing due to metamorphoses - it becomes more and more centrifugal. New professions develop, which are largely facilitated by the digital factor. At the same time precarization has come into our life - in the labor market it is manifested in the growing decentralization of employment: registered and unregistered unemployment is increasing, full-time work is replaced by part-time 'fluid' employment, the boundaries between working and non-working time disappear. Precarization displaces many professions from the labor market including even those that involve high qualification. There is a 'paradoxical metamorphosis': "in many countries of the world we have the best ever educated generation, which, however, is threatened by a hitherto unknown degree of unemployment" [3. P. 196].

Digitalization penetrates into the family relations producing conflicts of interest between love, family and personal freedom - the traditional family turns into the family 'for now': one can see 'love at a distance' and the rise of 'world families' [4]. As a result, traditional gender roles change, which creates risks for both men and women (late birth of the first child, divorces).

A specific kind of digital risks is the 'digital freedom risk' that "was not triggered by a catastrophe in the traditional sense. Rather, it was triggered by the mismatch between the perceived and the actual reality of freedom in contemporary (Western) societies... The real catastrophe would actually be an unseen hegemonic control on the global scale" [3. P. 141 - 142]. People who value individual freedoms will be particularly affected by this 'liquid' new catastrophe, which, while being invisible, undermines the protection of privacy as a fundamental human right.

Second, the conception of the digital turn in sociology is based on a number of important postulates. Many scientists accept the demand for innovative approaches to the analysis of the effects of 'arrow of time' and new complex social and natural 
realities. To make a description of these realities, it was necessary to pass from linear to non-linear knowledge and to study integrally both manifest and latent side effects of innovations. There are new paradigms based on the synthesis of sociological approaches with other sciences such as: the linguistic turn (L. Wittgenstein, M. Heidegger, M. Foucault); the risk turn (U. Beck, A. Giddens, N. Luhmann); the cultural turn (J.C. Alexander); the complexity, mobility, and resource turns (J. Urry), etc. The theoretical-methodological instruments of these turns contributed significantly to the analysis of network societies, technologies and environments but they are limited as far as the analysis of the digital is concerned.

The essence of the proposed digital turn is fundamentally different from other turns: despite the integral nature of all these turns, they suggest some determinism (for example, the focus is on the great role of discourse in the analysis of social-cultural realities or on factors of 'new catastrophism' in the interpretation of climate turbulences). The digital turn does not have any determinism, because the digital reality is a super complex one, presented, in particular, in many devices of artificial intellect or in the digital world of 'smart' machines with super-complex content, or in the very digital life. The digital turn's influence on society and man is many-sided and multiple. The diagnostics of the digital turn cannot be conducted by focusing on a particularly important role of some factors or specific methodologies for it is based on the results of all previous turns but also uses the new methodological concepts such as 'united cities', 'cosmopolitan communities of risk', 'expropriation through risk', 'metamorphosis of traffic', 'metamorphosis of conflict' and many others [3. P. 164-179]. All these new concepts and approaches emphasize that the consequences of digitalization are multiple and ambivalent. Thus, on the one hand, N. Marres argues that "'the digital' entails changes in the relations between technologies and social life; between knowledge, society and technology" [18. P. 11]; and J. Bustillos sees the benefits of digital technologies in "enabling and generating a new response-ability to both students and educators" [6. P. 159]. But, on the other hand, as W.H. Vanderburg states, digitalization negatively effects 'the human spirit' [24]; and V. Mosco believes that people are sometimes unaware of the total digital surveillance and collection of information about them [19. P. 166].

Certainly, digitalization affects ambivalently the essence of the contemporary risk defined as the anticipation of dangers and bads. The digital reality gives birth to a paradox of the coexistence of riskophobia and riskophilia [16. P. 3-13]. Some people prefer a rooted, imbedding lifestyle prone to riskophobia, anticipate the risks of 'expropriation' of humanism and human spirit promoted by digitalization, seek to avoid the consequences of risks considered as extremely unfavorable for life and culture, and see the salvation from such risks in stable social practices. Other people, especially the youth, tend to riskophilia: their lifestyle includes dangerous professional activities (participation in rescue operations, playing on the stock exchange, etc.) or risky fun practices and enjoyments (football fans' fighting, 'adventure holidays'). Quite often riskophilia activities involve the use of innovative technical and digital devices. These practices develop motives of pleasure from the anticipation of risks and their consequences - over- 
coming the boundaries between themselves and digital realities. In fact, a new social type of digital risk-taker has emerged, whose behavior and thinking aims at developing courage, will, self-esteem, the ability to produce risk spectacular performances for global audiences.

All previous turns in sociology aimed at understanding the results of revolutionary transformations in specific social spheres. The digital turn affects practically all social spheres. On the one hand, it scientifically analyzes new complex metamorphoses and especially the digital metamorphosis: according to U. Beck, it is "essentially different from digital revolution. Digital revolution describes a mainly technologically determined social change... the notion of revolution suggests that change is intentional, linear and progressive... Digital metamorphosis, on the contrary, is about non-intentional, often unseen side effects, which create metamorphosed subjects, - i.e. digital humans". On the other hand, the digital turn as compared with other turns "weaves together new patterns what were previously thought of as separate: cooperation and competition; economy and environment; equality and inequality; solidarity and self-interest; localism and cosmopolitanism. None of these binaries works any longer if we want to capture and diagnose the metamorphosis" [3. P. 145-146, 180].

Third, practically there is no systemic management and regulation of digitalization. Public administration should be reoriented from large-scale social communities (classes, nations), which, as B. Anderson argues, become 'imagined communities' [1], to fragmented social associations even limited by space-time boundaries. The governors should take into account the weakening traditional institutions (family, neighborhood, school, labor collective) that previously contributed to the adaptation of the younger generations to the uncertainties and risks in their life. It is necessary to learn to manage the emerging digital realities, whose functionality is based on the interests of relatively small, 'shortterm' social groups including young families, sport and fan organizations, representatives of the precariat.

It is important to support initiatives of developing slow, smart, and humane digital practices aimed at maintaining the role of life-worlds and imbedding lifestyles. Humanistic trends in digitalization can be implemented in the centers of sports, health, recreation, in incubators of scientific and business initiatives, in cooperation and competition while selecting candidates for management positions. In the educational sphere it is necessary to help students to learn both benefits and side effects of digitalization, which will make the intellectual foundations for the integral management of economy and environment to support their synchrony. M. Castells argues that "there is no such thing as a non-human economy. There is an inhuman economy". However, there are already practices "aimed at finding new forms of economic activity... including the search for ecological production and consumption that would be compatible with living together on the blue planet" [7. P. 3, 209].

Digitalization affects equality and inequality, solidarity and self-interest. Society needs to purposefully create a stable moral atmosphere based on the triumph of social justice, honoring winners in different solidarity activities. It is necessary to overcome 
social fears of numerous and complex reasons, among them not so much the real digital risks but rather the anticipation of dangerous inequalities produced by the digital. These social fears can be overcome if we develop new humanistic patterns adequate to contemporary complex realities.

In order to effectively manage digitalization, there is a request to scientists and political elites to use integrally the instruments and achievements of different turns, and such integralism cannot be a mechanical simple unity of advanced scientific achievements. A special emphasis should be made on the move of social and humanitarian theories to the interaction of their theoretical and methodological approaches with natural sciences, in particular, with the theories of chaos, complexity, new catastrophism [12]. This mutual integralism of turns would create the possibilities to go beyond disciplinary borders and to acquire a complex interdisciplinary knowledge that would allow, on the one hand, to take into account all possible paradoxes, digital metamorphoses and their consequences, and, on the other hand, to search for and approve forms of humanism adequate to the epoch of digitalization, including the humanistic orientation of any scientific research and innovation as an ethical imperative.

W.H. Vanderburg analyzes the side effects of digitalization expressed in the metamorphosis of human relations into technical ones and argues: "In contemporary mass societies, each new generation must gradually be socialized into a technical order, even though doing so begins with entering what little remains of the culture-based connectedness... children and teenagers become more dependent on 'googling' everything, causing them to leave behind what little they have acquired of a symbolic universe of sense" [24. P. 261, 263]. R. Braidotti tries to develop a new type of humanism underlining that "contemporary science and technologies affect the very fiber and structure of the living and have altered dramatically our understanding of what counts as the basic frame of reference for the human today" [5. P. 40]. In fact, we have begun to change all cultural meanings and values according to the digital world and digital humans. Accordingly, these digital realities qualitatively change the meanings of humanism, happiness, and justice. They were social-cultural, rooted in values and norms, but nowadays they are becoming digital: successes in life and ontological security are largely determined by individuals' adaptations to the digital environment. People, being exposed to digital codes of signification of God and Evil, become more and more dependent on technological realities that determine the nature of their behavior. And the mode of thinking is especially deformed: outside the rooted cultural values and life-worlds it is simplified to the functioning of digital technology. Under such conditions the unity of the digital and humanistic turns is of particular importance.

Digitalization is a great challenge to sociology. The digital risks and metamorphoses have not only determined social and cultural changes but radically transformed the nature of society and man, taking them out of the social bonds and cultural life-worlds. To meet these challenges scholars from different fields have begun to develop new integral approaches with a humanistic essence. There is a hope that scientists and then politicians would use the integral achievements of the digital and humanistic turns to ensure 
the transition of societies to a fundamentally different trend of development with the cultural foundations of all digital practices. New cosmopolitan actors of change presented by scientific communities are increasingly supporting humanization of digitalization with an awareness that alternative life-worlds, humane in nature, should be formed - one can already see the birth of new ethical realities based on humanism, solidarity, and security instead of pragmatism and formal rationalism.

\section{References}

[1] Anderson B. Imagined Communities: Reflections on the Origin and Spread of Nationalism. London: Verso; 1983.

[2] Beck U. World at Risk. Cambridge: Polity Press; 2010.

[3] Beck U. The Metamorphosis of the World. Cambridge: Polity Press; 2016.

[4] Beck U., Beck-Gernsheim E. Distant Love: Personal Life in the Global Age. Beck-Gernsheim; 2014.

[5] Braidotti R. The Posthuman. Cambridge: Polity Press; 2015.

[6] Bustillos J. The digital divide. Neoliberal imperatives and education. S. Isaacs (Ed.). European Social Problems. London — New York: Routledge; 2017.

[7] Castells M. (Ed.) Another Economy is Possible. Cambridge: Polity Press; 2017.

[8] Castells M. The Rise of the Network Society. Oxford: Wiley-Blackwell; 2010.

[9] Elliott A., Urry J. Mobile Lives. New York: Routledge; 2010.

[10] Goffman E. Stigma: Notes on the Management of Spoiled Identity. New York: Simon and Schuster; 1963.

[11] Goffman E. On cooling the mark out: Some aspects of adaptation to failure. Psychiatry. 1952; 15 (4).

[12] Kravchenko S.A. Sociology on the move to interaction of theoretical and methodological approaches. Sotsiologicheskie Issledovania. 2011; 1 (In Russ.).

[13] Kravchenko S.A. Becoming complex social reality: Issues of vulnerabilities. Sotsiologicheskie Issledovania. 2013; 5 (In Russ.).

[14] Kravchenko S.A. 'A normal anomie': Contours of conception. Sotsiologicheskie Issledovania. 2014; 8 (In Russ.).

[15] Kravchenko S.A. Metamorphoses: Essence, increasingly complex types, place in sociology of knowledge. Sotsiologicheskie Issledovania. 2017; 10 (In Russ.).

[16] Kravchenko S.A. The coexistence of riskophobia and riskophilia — an expression of 'normal anomie'. Sotsiologicheskie Issledovania. 2017; 2 (In Russ.).

[17] Kravchenko S.A., Perova A.E. 'New catastrophism' and the future: The demand for non-linear knowledge. RUDN Journal of Sociology. 2014; 17 (4).

[18] Marres N. Digital Sociology. The Reinvention of Social Research. Cambridge: Polity Press; 2017.

[19] Mosco V. Becoming Digital. Toward a Post-Internet Society. Bingley: Emerald Publishing Limited; 2017.

[20] Perrow Ch. Normal Accidents: Living with High Risk Technologies. New Brunswick: Rutgers University Press; 1999.

[21] Perrow Ch. The Next Catastrophe: Reducing our Vulnerabilities to Natural, Industrial, and Terrorist Disasters. Princeton University Press; 2011.

[22] Prigogine I. The End of Certainty. New York: Free Press; 1997.

[23] Urry J. Climate Change and Society. Malden: Polity Press; 2011.

[24] Vanderburg W.H. Our Battler for the Human Spirit: Scientific Knowing, Technical Doing, and Daily Living. Toronto: University of Toronto Press; 2016. 


\title{
Социология в движении: востребованность гуманистического цифрового поворота*
}

\author{
С.А. Кравченко \\ Московский государственный институт международных отношений \\ (Университет) Министерства иностранных дел России \\ просп. Вернадского, 76, Москва, 119454, Россия \\ Федеральный научно-исследовательский социологический центр \\ Российской академии наук \\ ул. Кржижановского, 24/35, стр. 5, Москва, 117218, Россия \\ (e-mail: sociol7@yndex.ru)
}

\begin{abstract}
Цифровизация социума имеет амбивалентные последствия: появились новые достижения («умные» технологии, искусственный интеллект, доступ к разнообразному знанию), однако возникли и цифровые риски и метаморфозы, травмирующие человеческий дух, поведение и мышления людей, высвобождая их из контекста социальных связей и жизненных миров. Данный процесс стал вызовом для социологии и других наук - разрабатываются новые подходы, среди которых цифровой и гуманистический повороты. Автор анализирует воздействие цифровизации на социум и человека (производство метаморфоз и побочных эффектов, порождающих новые сложные риски), разрабатывает контуры концепции «цифрового поворота в социологии», показывая его суть в сравнении с более ранними методологическими поворотами (лингвистическим, рискологическим, культурным и пр.), предлагает средства, позволяющие минимизировать побочный ущерб реализуемого сегодня типа цифровизации, - в частности, развитие социологии в направлении интеграции ресурсов цифрового и гуманистического поворотов. В статье утверждается, что новые вызовы человечеству и научному знанию проистекают не столько из самого процесса цифровизации, сколько от его нынешнего типа - основанного на принципах формальной рациональности, прагматизма и меркантилизма, фактически игнорирующих жизненные миры людей. Данный тип цифровизации не является универсальным и может быть заменен на альтернативный гуманистический ее вариант. Чтобы начать переход к гуманистическому тренду развития цифровизации, ученым следует интегрировать теоретический инструментарий цифрового поворота с другими междисциплинарными подходами, в первую очередь, с гуманистическим поворотом.
\end{abstract}

Ключевые слова: сложный социум; цифровизация; побочные эффекты; цифровые риски; цифровая метаморфоза; центробежные тенденции; цифровой поворот; гуманистический поворот

* (C) Кравченко С.А., 2019.

Статья поступила 03.04.2019. Статья принята к публикаџии 23.05.2019 2. 